\title{
PHYTOCHEMICAL SCREENING AND PHYSIOCHEMICAL STUDIES ON AERIAL PART OF ACHILLEA MILLEFOLIUM LINN. FOUND IN KASHMIR
}

\author{
Suheena Khanday ${ }^{1 *}$, Afsahul Kalam, ${ }^{2, *}$ Ansar Ahmad Ansari², \\ Aamir Yousuf ${ }^{1}$, Sajad Salim ${ }^{1}$, Riehana Gani ${ }^{3}$ \\ ${ }^{1} \mathrm{MD}$ in Ilmul Advia at Regional Research Institute of Unani Medicine \\ Hazratbal, Srinagar, J\&K, 190006 India \\ ${ }^{2}$ Research Officer in Ilmul Advia Department of Regional Research Institute of Unani Medicine \\ Hazratbal, Srinagar, J\&K, 190006 India \\ ${ }^{3}$ SRF-Pharmacognosy in Ilmul Advia at Regional Research Institute of Unani Medicine \\ Hazratbal, Srinagar, J\&K, 190006 India
}

Research Paper

Received: 15.08.2021

Revised: 22.08.2021

Accepted: 05.09.2021

\section{ABSTRACT}

This studyis aimed to evaluate the physicochemical, macroscopic, microscopic and preliminary phytochemical studies of the aerial part of Achillea millefolium L., belonging to the Asteraceae family. It is a perennial herb and is distributed throughout the worldandis native to western Asia and Europe but is also found abundantly in most temperate regions including North America (Anne et al., 2006). Western Himalayas from Kashmir to Kumaon (6000-9000 feet above sea level), also serve as a good source for its production. The plant possesses many important phyto-chemicalslike sesquiterpenes, phenolic compounds, essential oils, etc. The plant has anti-inflammatory, antioxidant, antifungal, antitumor, antiseptic, spasmolytic and hemostatic properties. As there is no detailed standardization work reported on aerial part of Achillea millefolium L., the objective of this study was to work out the physicochemical parameters, macroscopic and microscopic study and preliminary phytochemical constants. The study revealed specific identities for the crude drug which will be useful in identification and to check the adulteration of the raw drug.

\begin{tabular}{|llll}
\hline No. of Pages: 7 & No. of Tables: 8 & No. of Figures: 9 & References: 20 \\
\hline
\end{tabular}

Keywords: Achillea millefolium L., physicochemical studies, macroscopic study, microscopic study, preliminary phytochemical studies.

\section{INTRODUCTION}

Achillea millefolium L., belonging to the family Asteraceae (Bremer 1994), is a well-known 15-90 cm high perennial and erect herb with stoloniferous roots. The stem is grooved and leafy. The shape of leaves is oblong-lanceolate, alternately arranged and 3-pinnatisect which is divided minutely giving it a feathery look (Kritikar and Basu, 2012, Radusiene and Gudaityte, 2005). It has been very commonly used in folk as well as conventional medicine for more than 3000 years (Radusiene and Gudaityte, 2005). Traditionally, it has been used for diseases like kidney stones, high blood pressure, hemorrhoids, bruises, menstrual disorder, malaria, hepatitis, jaundice, headache, cough, influenza, etc. (Usmanghani et al., 1997). The presence of chemical constituents, viz., Sesquiterpenes, phenolic compounds and essential oils etc., credits Achillea millefolium L. with a number of

*Corresponding author: suhinakhanday@gmail.com 
pharmacological activities like anti-inflammatory, antioxidant, antifungal, antitumor, antiseptic, spasmolytic, hemostatic, cholagogue hepatoprotective and lithotriptic effects (Karamenderes and Apaydin, 2003; Stojanovic et al., 2005; Cavalcanti et al., 2006; Si et al., 2006; Tajik et al., 2008; Fierascu et al., 2015., Khanday et al., 2021). The most active part of the plant are its flowering tops which contain the essential oil and are used chiefly for the treatment of hemorrhage, diarrhea, influenza, dysmenorrhea and as a haemostatic (Baser et al., 2002; Benedek et al., 2008).

\section{MATERIALS AND METHODS}

\section{Plant Material Collection:}

In the present study, the fresh plant of Achillea millefolium L. was collected in July, 2018 at an altitude of 2,740m from Pahalgam, Anantnag, Kashmir. The plants were identified and authenticated by Prof. Akhtar Malik, KASH Centre for Biodiversity and Taxonomy, University of Kashmir under Specimen Voucher no. 2700-(KASH).

\section{Physico-Chemical Evaluation}

The air dried coarse powdered aerial part of Achillea millefolium L. was subjected to undergo certain physical and chemical processes to estimate the ash values (total ash, water soluble ash, acid insoluble ash, sulphated ash); extractive values (water soluble extractive value, alcohol soluble extractive value) and also moisture content (loss on drying). The procedures were followed as per Indian pharmacopeia, 1996. All the calculated values are presented in Table no: 1 .

\section{Preliminary phytochemical screening}

The dried and coarsely powdered material of Achillea millefolium L. was subjected to successive extraction in Soxhlet apparatus with different solvents in increasing order of their polarity, viz; pet-ether 60/80, chloroform, ethyl acetate, methanol, acetone, hydro-alcohol and water. The extracts of Achillea millefolium $\mathrm{L}$. was subjected to phytochemical screening to identify various constituents like alkaloids, glycosides, tannins, carbohydrates, flavonoids, proteins, saponins, terpenoids and phytosterols, present in them (WHO 1998, Chaudhar 1996). (Table 2)

\section{Macroscopic Evaluation}

The detailed macroscopic evaluation is necessary to differentiate between the related species having similar appearance (Anonymous, 1998). The macroscopic evaluation involved the detailed study of the visual appearance and sensory profile of the crude drug sample (Table 3, 4 and 5). Figure 1 shows the measurements of leaves and Inflorescence of the plant.

\section{Microscopic Evaluation}

\section{a) Powder study}

The leaves, stem and flowers of Achillea millefolium L. were powdered separately and both stained and unstained slides were prepared. These slides were then observed under microscope. Figure 2 shows the powder microscopy of Achillea millefolium L. showing part of hypanthium parenchyma cells and Parenchyma. Figure 3 shows the portion of vita and Endocarp layer and figure 4 shows the Glandular trichomes of Achillea millefolium L. Figure 5 and 6 show oil glands and Xylem vessels respectively under microscope.

\section{b) Transverse section}

For microscopic evaluation, free hand sections of the fresh stem of Achillea millefolium L. were then cut and cleared with chloral hydrate solution and water. Both stained and unstained sections were prepared. Sections were stained with phloroglucinol and hydrochloric acid in the ratio of 1:1 (Tyler et al, 1981, Brain et al, 1975). Figure 7 and 8 show stained slides of transverse section of stem and xylem \& phloem respectively of the plant.

Thin layer Chromatography (TLC)

The Pet ether, Ethyl acetate and Methanolic extracts of Achillea millefolium L. were subjected to TLC profiling. Suitable solvent system was developed to act as mobile phase for these extract solutions. For Pet ether extract of Achillea millefolium L., the solvent system developed was 7\% ethyl acetate in $93 \%$ of Hexane. For Ethyl acetate extract of the plant, the solvent system that was developed was $25 \%$ ethyl acetate in $75 \%$ of Pet ether. For Methanolic extracts of Achillea millefolium (Linn.), the solvent system developed was $20 \%$ of chloroform in $80 \%$ of Methanol. The retention factor (Rf) values were correspondingly calculated and showed in the table no. 6, 7, 8. Figure 9 shows TLC profile of extracts in Achillea millefolium L. in various solvents.

\section{RESULTS}

Table 1: Physicochemical standards of powdered aerial part of Achillea millefolium L.

\begin{tabular}{|lll|}
\hline S. No. & Parameters & $\mathbf{\%}(\mathbf{w} / \mathbf{w})$ \\
\hline 1. & Total ash & 7.4 \\
\hline 2. & Water soluble ash & 3 \\
\hline 3. & Acid insoluble ash & 1.33 \\
\hline 4. & Sulphated ash & 10 \\
\hline 5. & Water soluble extractive & $0.23 \mathrm{~g}$ \\
\hline 6. & Alcohol soluble extractive & $0.02 \mathrm{~g}$ \\
\hline 7. & Loss on drying & 80 \\
\hline
\end{tabular}


Table 2: Preliminary phytochemical study on Achillea millefolium L. extracts.

\begin{tabular}{|c|c|c|c|c|c|c|c|c|}
\hline Tests for & $\begin{array}{l}\text { Name of } \\
\text { the Test }\end{array}$ & $\begin{array}{l}\text { Pet ether } \\
\text { extract }\end{array}$ & $\begin{array}{l}\text { Chloroform } \\
\text { extract }\end{array}$ & $\begin{array}{l}\text { Ethyl acetate } \\
\text { extract }\end{array}$ & $\begin{array}{l}\text { Methanol } \\
\text { extract }\end{array}$ & $\begin{array}{l}\text { Acetone } \\
\text { extract }\end{array}$ & $\begin{array}{l}\text { Hydro } \\
\text { Alcoholic }\end{array}$ & $\begin{array}{l}\text { Aqueous } \\
\text { extract }\end{array}$ \\
\hline & Mayer's test & - & - & - & - & - & - & - \\
\hline \multirow{4}{*}{ Alkalides } & $\begin{array}{l}\text { Tannic acid } \\
\text { test }\end{array}$ & - & - & - & - & - & - & - \\
\hline & Wagner's test & - & - & - & - & - & - & - \\
\hline & $\begin{array}{l}\text { Dragendroff's } \\
\text { test }\end{array}$ & + & + & + & + & + & + & + \\
\hline & Hager's test & - & - & - & - & - & - & - \\
\hline \multirow{3}{*}{ Glycosides } & $\begin{array}{l}\text { Borntrager's } \\
\text { test (for the } \\
\text { presence of } \\
\text { anthro- } \\
\text { quinones). }\end{array}$ & - & - & - & - & - & - & - \\
\hline & $\begin{array}{l}\text { Keller killiani } \\
\text { test (for the } \\
\text { presence of } \\
\text { Cardiac } \\
\text { glycosides). }\end{array}$ & - & - & - & + & + & + & - \\
\hline & $\begin{array}{l}\text { Legal's test } \\
\text { (for the } \\
\text { presence of } \\
\text { Cardiac } \\
\text { glycosides). }\end{array}$ & + & + & + & + & - & - & - \\
\hline \multirow{2}{*}{ Tannins } & $\begin{array}{l}\text { Ferric } \\
\text { chloride test }\end{array}$ & - & - & - & - & - & $+($ catechol $)$ & + (catechol) \\
\hline & $\begin{array}{l}\text { Lead acetate } \\
\text { test }\end{array}$ & - & - & - & + & + & + & + \\
\hline \multirow[t]{4}{*}{ Carbohydrates } & Molisch's test & + & + & + & + & + & + & + \\
\hline & Benedict's test & - & + & + & + & + & + & + \\
\hline & Fehling's test & + & + & + & + & + & + & + \\
\hline & Barford's test & - & - & + & + & + & + & + \\
\hline \multirow[t]{2}{*}{ Flavonoids } & $\begin{array}{l}\text { Alkaline } \\
\text { reagent test }\end{array}$ & - & - & - & + & + & - & - \\
\hline & Zinc test & - & - & + & + & + & - & - \\
\hline Protein & $\begin{array}{l}\text { Ninhydrin test } \\
\text { Millon's test }\end{array}$ & - & - & - & + & + & + & $\begin{array}{l}+ \\
+\end{array}$ \\
\hline \multirow[t]{3}{*}{ Saponins } & $\begin{array}{l}\text { Lead acetate } \\
\text { test }\end{array}$ & - & - & - & + & - & - & + \\
\hline & Froth test & & & & & & + & \\
\hline & Foam test & & & & & & + & \\
\hline Terpenoids & Salkowski test & + & + & - & - & - & - & - \\
\hline Sterols & Salkowski test & + & + & - & - & - & - & - \\
\hline
\end{tabular}


Table 3:Macroscopic characters of stem of Achillea millefolium $\mathrm{L}$.

\begin{tabular}{|l|l|l|}
\hline S. No. & Parameters & Achillea millefolium $\mathbf{L}$. \\
\hline 1. & Color & Dark green \\
\hline 2. & Odor & Sharp/pungent \\
\hline 3. & Taste & Bitter \\
\hline 4. & Length & 2-3 meters \\
\hline 5. & Condition & Fresh \\
\hline 6. & Type & Branched \\
\hline 7. & Surface & Ridged \\
\hline 8. & Texture & Hairy/pubescent \\
\hline 9. & Fracture & Fibrous \\
\hline
\end{tabular}

Table 5: Macroscopic characters of leaves of Achillea millefolium L.

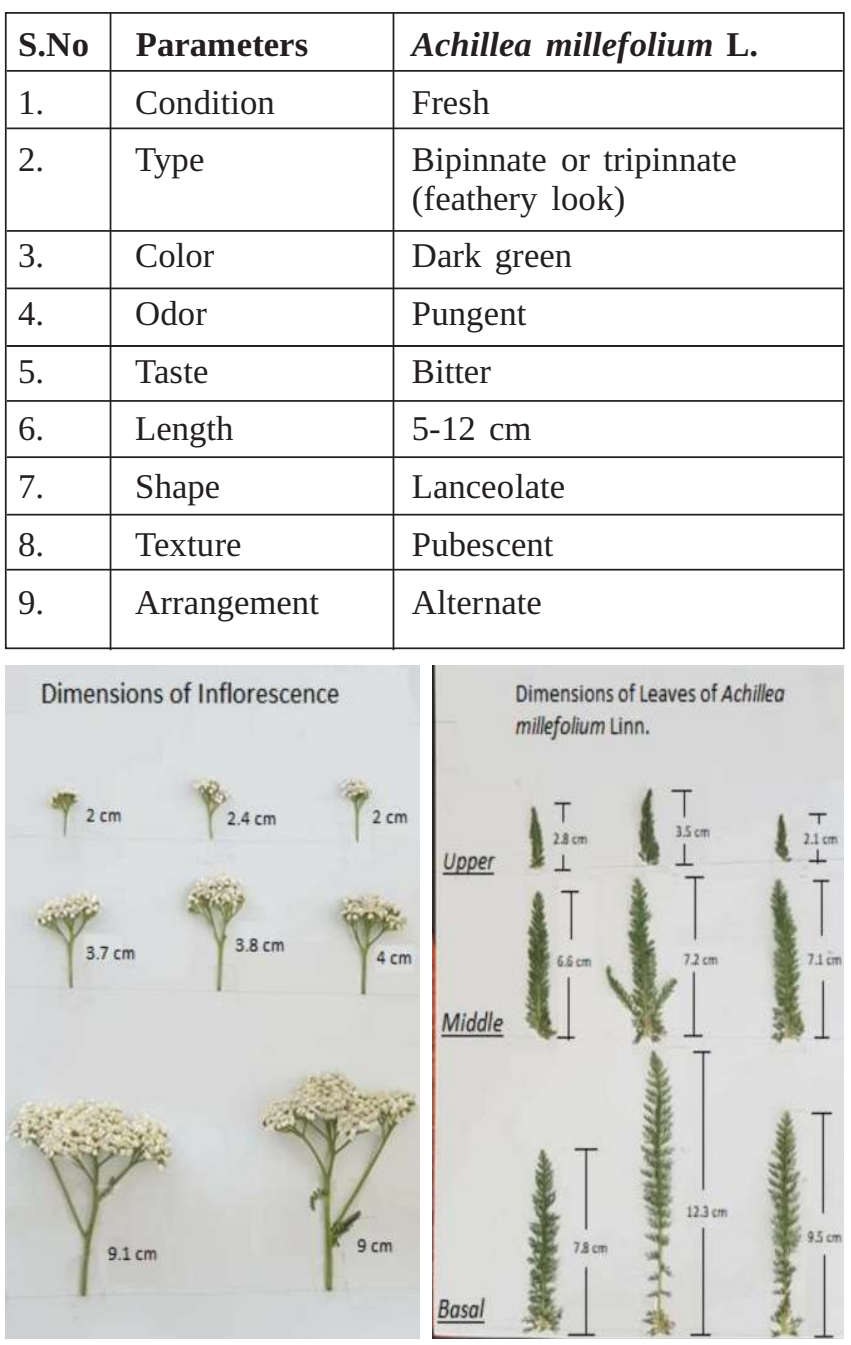

Figure 1: Measurements of (a) leaves (b) Inflorescence of plant Achillea millefolium L.
Table 4: Macroscopic characters of flowers of Achillea millefolium $\mathrm{L}$.

\begin{tabular}{|l|l|l|}
\hline S.No & Parameters & Achillea millefolium L. \\
\hline 1. & Condition & Fresh \\
\hline 2. & Type & Compositae \\
\hline 3. & Inflorescence & Corymb \\
\hline 4. & Phyllaries & $4-9$ \\
\hline 5. & Number of disk & flowers 15-40 \\
\hline 6. & $\begin{array}{l}\text { Number of ray } \\
\text { flowers }\end{array}$ & 3-8 usually 5 \\
\hline 7. & Size of corymb & 4-5cm \\
\hline 8. & $\begin{array}{l}\text { Color of ray } \\
\text { flower }\end{array}$ & White \\
\hline 9. & $\begin{array}{l}\text { Color of disk } \\
\text { flower }\end{array}$ & Yellow \\
\hline 10. & Flowering & Summer (June-July) \\
\hline 11. & $\begin{array}{l}\text { Shape of ray } \\
\text { flower }\end{array}$ & Ovate to round \\
\hline 12. & $\begin{array}{l}\text { Length of ray } \\
\text { flower }\end{array}$ & 2-3 mm \\
\hline 13. & Odor & Sharp/characteristic \\
\hline
\end{tabular}
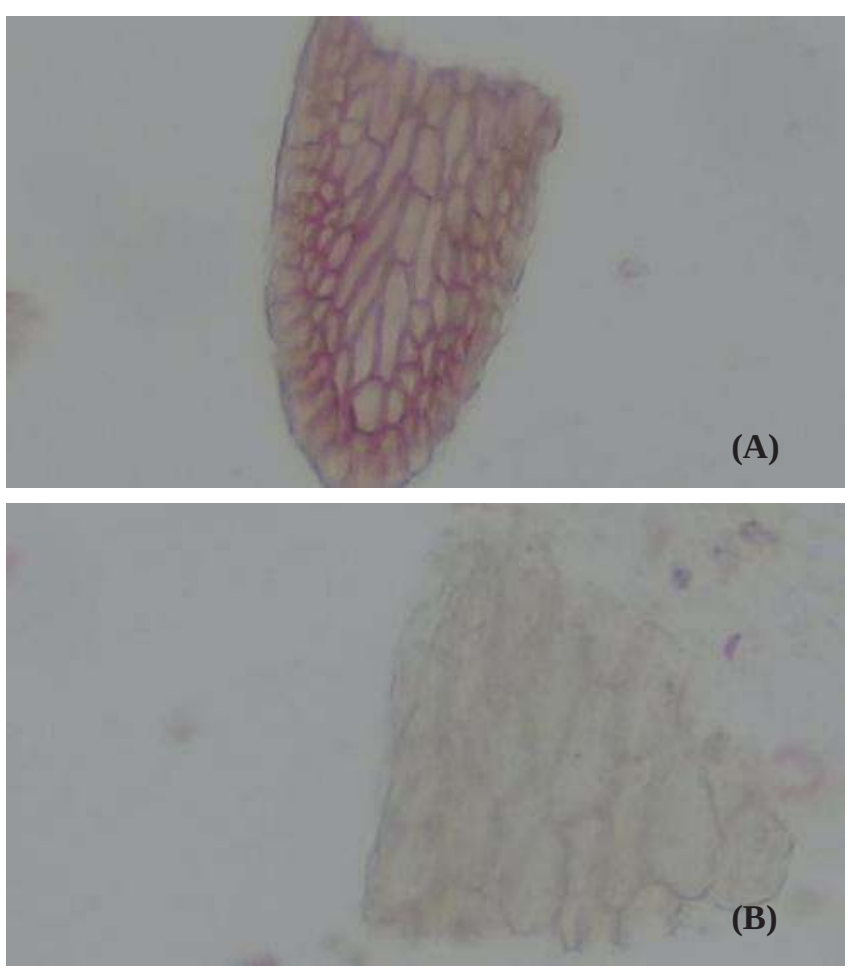

Figure 2: Photographs of Achillea millefolium L. showing a)Part of hypanthium showing parenchyma cells and b) Parenchyma of Achillea millefolium L. 


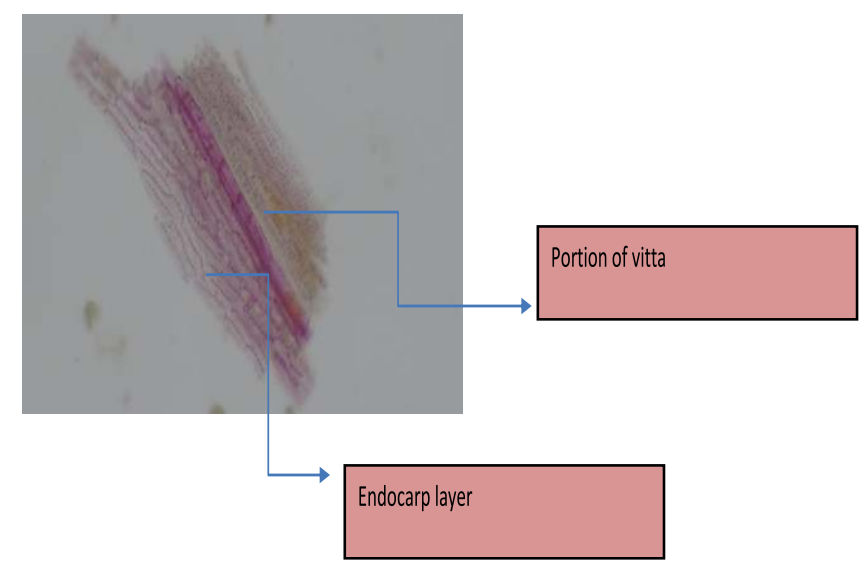

Figure 3:Photograph showing Portion of vita and Endocarp layer of Achillea millefolium $\mathrm{L}$.

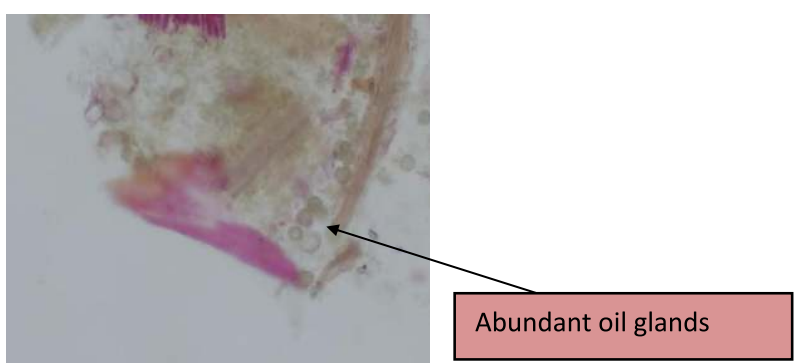

Figure 5: Figure showing oil glands of Achillea millefolium L. under microscope.

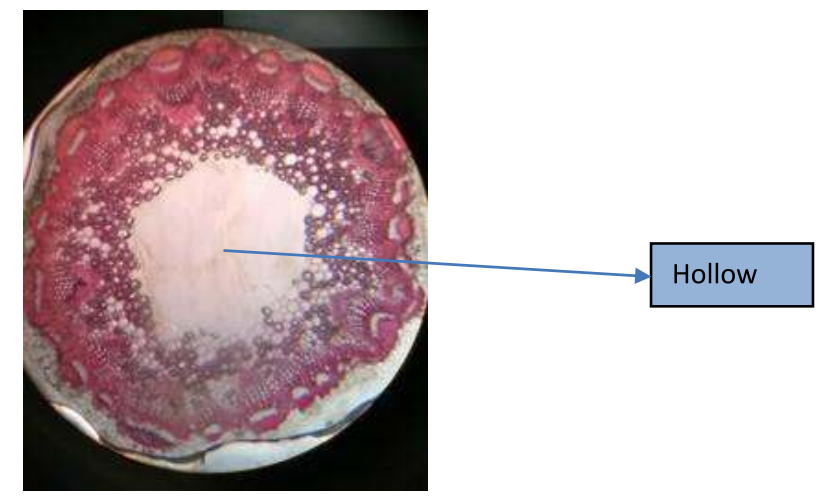

Figure 8: Stained slide showing Xylem and phloem.

Table 6: TLC Profile of Pet Ether extract of Achillea millefolium $\mathrm{L}$.

\begin{tabular}{|l|c|c|c|c|}
\hline $\begin{array}{l}\text { No. of } \\
\text { Spots }\end{array}$ & Spot 1 & Spot 2 & Spot 3 & Spot 4 \\
\hline $\mathbf{R}_{\mathrm{f} V a l u e}$ & 0.49 & 0.52 & 0.63 & $\begin{array}{c}0.825 \\
\text { (UV Visible) }\end{array}$ \\
\hline
\end{tabular}

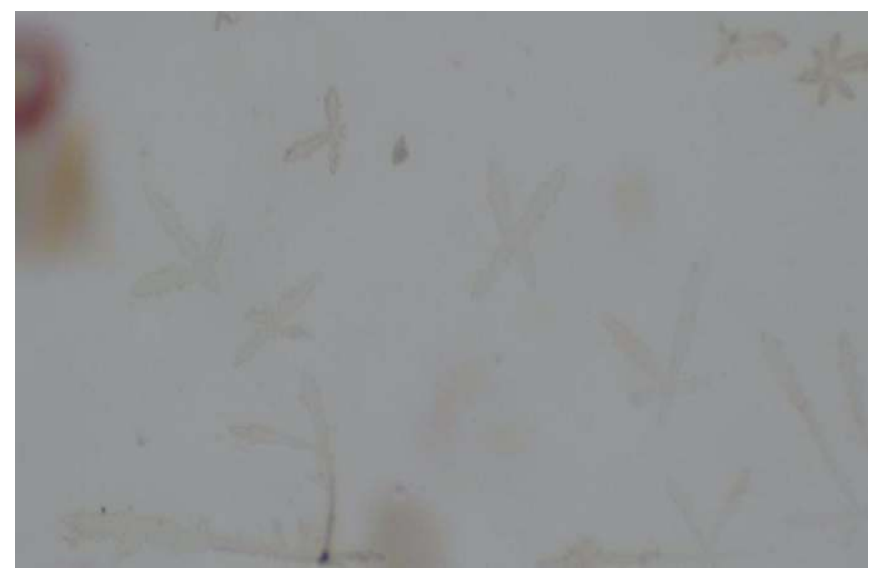

Figure 4: Photograph showing Glandular trichomes of Achillea millefolium $\mathrm{L}$.

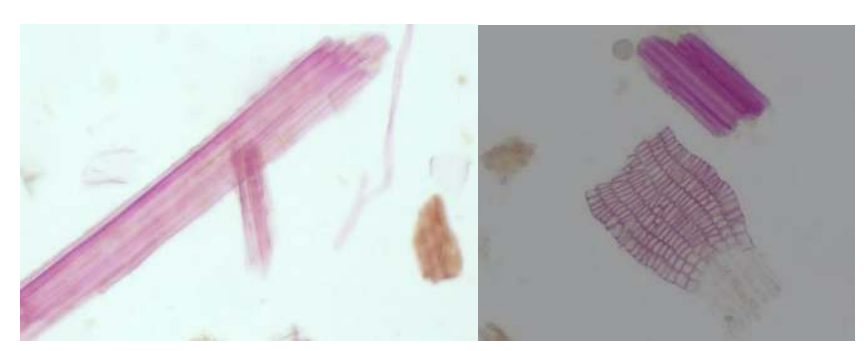

Figure 6: Figure showing Xylem vessels of Achillea millefolium L. under microscope.

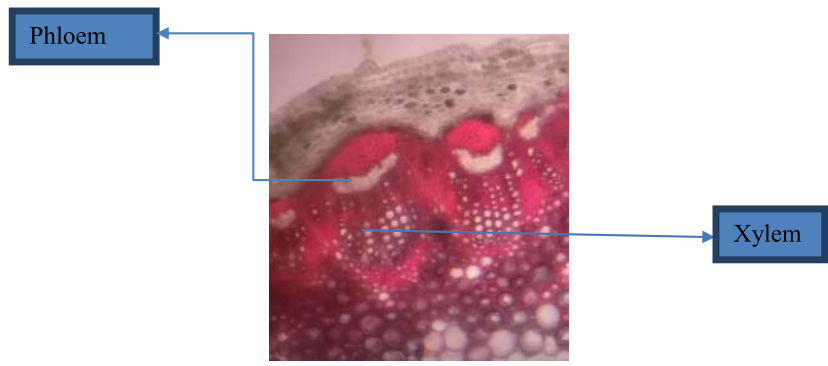

Figure 7: Stained slide, showing transverse section of stem of Achillea millefolium L.

Table 7: TLC Profile of Ethyl Acetate extract of Achillea millefolium L.

\begin{tabular}{|l|c|c|c|c|}
\hline $\begin{array}{l}\text { No. of } \\
\text { Spots }\end{array}$ & Spot 1 & Spot 2 & Spot 3 & Spot 4 \\
\hline R Value & $\begin{array}{c}0.367 \\
\text { (UV Visible) }\end{array}$ & $\begin{array}{c}0.469 \\
\text { (UV Visible) }\end{array}$ & $\begin{array}{c}0.571 \\
\text { (UV Visible) }\end{array}$ & 0.75 \\
\hline
\end{tabular}


Table 8: TLC Profile of Methanol extract of Achillea millefolium $\mathrm{L}$.

\begin{tabular}{|l|c|}
\hline No. of Spots & RfValue \\
\hline Spot 1 & 0.533 (UV Visible) \\
\hline Spot 2 & 0.66 (UV Visible) \\
\hline
\end{tabular}

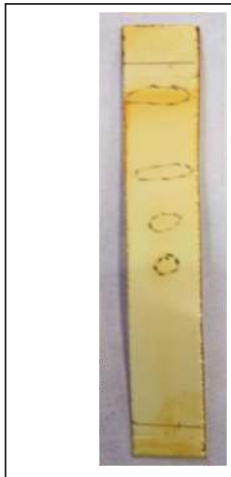

(a)

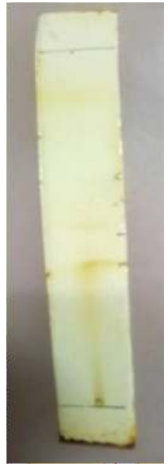

(b)

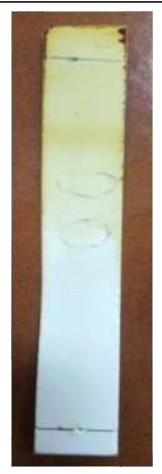

(c)
Figure 9: TLC Profile of (a) Pet Ether extract of Achillea millefolium Linn. in hexane and ethyl acetate solvent (b) Ethyl Acetate extract of Achillea millefolium Linn. in ethyl acetate and Pet ether solvent (c) Methanol extract of Achillea millefolium Linn. in Methanol and Chloroform solvent.

\section{DISCUSSIONAND CONCLUSION}

The present work demonstrates the pharmacognostical, physicochemical and preliminary phytochemical evaluation of aerial partof Achillea millefolium L. which will help in proper identification of this plant for future investigations.

The macroscopic examination of drugs refers to evaluation of drugs by color, odor, taste, size, shape and special features, like touch, texture etc. It is a technique of qualitative evaluation based on the study of morphological and sensory profiles of whole drugs. Organoleptic evaluation means conclusions drawn from studies resulting due to impression on organs of senses. All these parameters were recorded for the aerial parts of Achillea millefolium L. These shall be helpful in primary identification of the crude drugs under investigation.

The Macroscopical study of Achillea millefolium L. has revealed that it has pubescent, ridged and have many branches which arises from its roots. It has green tripinnate leaves giving it a feathery look.

Powder microscopy of Achillea millefolium L. reveals the presence of lignified spiral xylem vessels, oil glands and abundant vascular bundles.

Controlled incineration of crude drugs resulted in an ash residue consisting of inorganic materials (metallic salts and silica). This procedure was repeated thrice and the mean ash value was calculated as 7.4. This value varies within fairly wide limits and is therefore an important parameter for the evaluation of crude drugs. By ash value more direct contamination such as by sand or earth is detected. Sometimes inorganic variables like calcium oxalate, silica, carbonate content of crude drug affects "Total ash" values. Such variables are then removed by treating with acids (as they are soluble in hydrochloric acid) and then acid insoluble ash value is determined (Mukherjee, 2002). The acid insoluble ash value of aerial part of Achillea millefolium L. was found to be 1.33. The water insoluble ash was found to be 3 . The foaming index less than 100 and swelling index was found to be 3.14.

Extractive values are useful for the evaluation of crude drugs and give an idea about the nature of chemical constituents present in them. The amount of extractive a drug yields to a given solvent is often an approximate measure of a certain constituent or group of related constituents the drug contains. The alcohol and water soluble extractive value helps to determine the quality as well as purity of the drug. The water extractive value of Achillea millefoliumL. is 0.23 and alcohol extractive value is 0.02 . The $\mathrm{pH}$ value of Achillea millefolium at $1 \%$ solution and $10 \%$ solution was found to be 6.5 and 5.9 respectively which gives a clue towards its nature of being slightly acidic in nature. The percentage of active chemical constituents in crude drug is mentioned on air dried basis. Therefore, LOD of the plant material should be determined and moisture content should be controlled. The LOD of aerial part of Achillea millefolium was found to be $80 \%$.

The preliminary phytochemical tests were carried out for the identification of the nature of phyto-constituents present in Achillea millefolium L. All the results have been presented in tabular form in result section which revealed the presence of various phyto-constituents like carbohydrates, flavonoids, glycosides, alkaloids, tannins, phenolic compounds, sterols, saponins and terpenoids. Furthermore, this plant contains various important active phyto-constituents which can prove beneficial in treating various health related problems thereby serving mankind in a very useful way. A further progress of this studyis needed to explore and investigate the drug more thoroughly.

\section{CONFLICT OF INTEREST}

The Authors declare that they have no conflict of interest

\section{REFERENCES}

1. Bremer, K. 1994. Asteraceae: Cladistics and Classification. Timber Press, Portland, Oregon.

2. Kritikar, K.R. and Basu, B.D. 2012. Indian Medicinal Plants, Vol. II. Lalit Mohan Publication, Allahabad, 1375-1378. 
3. Radusiene J, Gudaityte O. 2005. Distribution of Proazulenes in Achillea millefolium wild populations in relation to phytosociological dependence and morphological characters. Plant Genet Resource 3: 136143.

4. Usmanghani K, Saeed A, Tanweer A 1997. Traditional uses of A. millefolium. Indus Med 1:93-95.

5. Karamenderes C, Apaydin S. 2003. Antispasmodic effect of Achillea nobilis L. subsp. Sipylea (O. Schwarz) Bassler on the rat isolated duodenum. J Ethnopharmacol. 84: 175-179.

6. Stojanovic G, Radulovic N, Hashimoto T, Palic R. 2005. In vitro antimicrobial activity of extracts of four Achillea species: the composition of Achillea clavennae L. (Asteraceae) extract. J Ethnopharmacol. 101: 185190.

7. Cavalcanti AM., Baggia CH., Freita CF., et al., 2006. Safety and anti ulcer efficacy study of Achillea Millefolium L. After chronic treatment Wistarats. J Ethnopharmocol; 107:277-84.

8. Si XT., Zhang ML., Shi QW., Kiota H., 2006. Chemical constituents of the plants in the genus Achillea. Chem Biodiverse 3;1163-1118.

9. Tajik HO, and Shokuhi Sabet Jalali F. 2008. In vitro assessment of antimicrobial efficacy of aqueous extract of garlic against wound-infecting microorganisms. Journal of Medicinal Plants. 2(26):10-5.

10. Fierascu I, Ungureanu C, Avramescu SM, Fierascu RC, Ortan A, Soare LC, Paunescu A. 2015. In vitro antioxidant and antifungal properties of Achillea millefolium L. Rom Biotechnol Lett. 20:10626-36.

11. Khanday S., Kalam A., Salim S., Yusuf S., Dar Y. 2021. Evaluation of In-vitro lithotriptic activity of
Baranjasif(Achillea millefolim Linn. Aerial Part Extracts). Indian Journal of Unani Medicine. Vol XIV, Iss.1, 46-55.

11. Baser KH, Demirci B, Demirci F, 2002. Composition and antimicrobial activity of the essential oil of acillea millefolium planta med 68; 941-43.

12. Benedek B, Rothwangi WK, Rozema E, et al. 2008. Yarrow (Achillea millefolium); Pharmaceutical quality of commercial samples. Pharmazie 63: 23-26.

13. World Health Organization. Quality control methods for herbal materials (updated edition of quality control methods for medicinal plant materials 2011. ISBN 978 9241500739.

14. Indian Pharmacopoeia. Government of India, Ministry of Health \& Family Welfare, Vol II, Controller of Publications , New Delhi, 1996, A-54-55.

15. Chaudhari, R.D., Herbal drug industry. $1^{\text {st }}$ ed.Eastern Publishers, New Delhi, 1996.

16. Anonymous. Quality Control Methods for Medicinal Plant Materials, World Health Organization, Geneva, 1998, 8, 25-28.

17. Tyler, V.E.; Brady, L.R.; Robbers, J.E. 1981. Pharmacognosy. Lea \& Febiger, Philadelphia.

18. Brain, K.R.; Turner, T.D. 1975. Practical evaluation of phytopharmaceuticals. John. Wright and Sons Ltd, London.

19. Bhat tacharya, S.; Zaman, M.K. 2009. Pharmacognostical evaluation of Zanthoxylum nitidum Root. Pharmacognosy Journal 2009, 1, 15-21.

20. Mukherjee, P. K. Quality Control of Herbal Drugs. Business Horrizons. New Delhi, 2002, 132-191. 